\title{
Challenges in Implementing the TVET Curriculum in Technical Colleges in Southern Nigeria
}

\author{
Chinyere Shirley Ayonmike ${ }^{1}$ \\ ${ }^{1}$ Delta State University, Abraka [E-mail: chinyereshirley@ymail.com]
}

\begin{abstract}
This study aimed at examining the challenges in implementing the Technical and Vocational Education and Training (TVET) curriculum in technical colleges in Southern Nigeria. It sought to respond to three research questions and was guided by one research hypothesis. A questionnaire with 14 items was used to collect data from 60 principals of technical colleges in Southern Nigeria. The data collected was analysed using frequency counts and percentages. The Chi-square goodness of fit test was used to verify the hypothesis stated at the .05 level of significance. The study revealed that poor funding, obsolete facilities and inadequacy of instructional materials are affecting implementation of the TVET curriculum in Southern Nigeria technical colleges. Based on the findings of the study it was recommended that stakeholders work collectively to address these challenges.
\end{abstract}

Keywords: Technical and vocational education; TVET; Curriculum innovation.

\section{Introduction}

Technical and Vocational Education and Training (TVET) is that aspect of education that exposes the learner to acquisition of demonstrable skills that could be transformed into economic benefits (Akerele, 2007). Also, UNESCO (2002) sees TVET as a comprehensive term which encompasses the study of technologies and related sciences, and the acquisition of practical skills, attitudes, understanding and knowledge related to occupations in various sectors of economic and social life. Implementation of the TVET curriculum in Nigerian technical colleges has not been yielding the expected outcomes. This is due to the fact that the aims and objectives of TVET as enshrined in the National Policy on Education (NPE) have not been met. However, this could be explained by the persistent petition by the labour market, that Nigerian 
graduates (TVET graduate inclusive) do not possess employable skills which could be traced to the implementation of the curriculum (TVET curriculum inclusive). According to National Board for Technical Education (NBTE, n.d) in Nigeria, there are one hundred and ten (110) state government technical colleges in Nigeria, while Southern Nigeria have sixty (60) state government technical colleges. Thus, this paper intends to examine technical college principals' opinion on the challenges of implementing TVET curriculum in Nigerian technical colleges.

\subsection{Meaning of Curriculum}

There is no universally accepted or precise definition of the term curriculum. The term has been with several meanings and a number of different definitions of its have been proposed (Ughamadu, 2006). Consequently, in spite of the problem of defining curriculum, it must be emphasized that curriculum experts and educators have reached some understanding as to what constitutes the term curriculum. According to Smith, Stanley and Shores (1957) in Ughamadu (2006), if an observer looks at the curriculum of the school in any given society, he or she will find, either stated or implied a set of educational goals and objectives, a body of subject matter, a list of exercises or activities to be performed (learning experiences) and a way of determining whether or not the objectives have been achieved by the learners (evaluation). Therefore, the term curriculum is defined as all experiences students go through in school during the course of their educational programmes (Caswell \& Campbell, 1935) in (Ughamadu, 2006).

In addition, Doll (1978) in Akinseinde (2004), defined the curriculum of a school as the formal and informal content and process by which learners gain knowledge and understanding, develop skills, and alter attitudes, appreciations, and values under the auspices of that school. Wojtczak (2002) in Arowolo (2010) posited that curriculum is an educational plan that spells out which goals and objectives have to be achieved, which topics should be covered and which methods are to be used for learning, teaching and evaluation. Also, Tanner and Tanner (1995:158) in Commonwealth of Learning (COL) (2000), defined curriculum as a plan or program of all experiences under the direction of a school. In same vein, Gatawa (1990:8) in (COL, 2000), opined that curriculum is the totality of the experiences of children for which schools are responsible. Bringing all the above points together, the curriculum is viewed as a composite while including the learner, the teacher, teaching and learning methodologies, anticipated and unanticipated experiences, outputs and outcomes possible within a learning institution (COL, 2000). 


\subsection{Curriculum Implementation}

This involves helping learners to acquire knowledge and as well as experience. It is important to note that curriculum implementation cannot take place without the learner (COL, 2000). The learner is the central figure in the curriculum implementation process. Implementation takes place as the learner goes through the intended experiences, knowledge, skills, ideas and attitudes that are aimed at enabling him/ her to function effectively in society. However, implementing TVET curriculum is not free from challenges.

\subsection{Challenges in Implementing the TVET Curriculum in Nigerian Colleges}

The challenges of implementing the TVET curriculum in Nigerian colleges are synonymous with the problems of TVET in Nigeria and also that of general education in Nigeria. Egwu (2009), posited that some of the major challenges of the Nigerian university system includes;

1. Institution related factor such as unstable academic calendar, inadequate collaboration between tertiary institutions and organized private sector, inadequate and obsolete infrastructure and equipment, for example poor equipped TVET workshop and libraries, dilapidated classroom blocks, and weak support structure for students Industrial Work Experience Scheme (SIWES).

2. Human resource related problems such as brain drain, human capital flight, unattractive conditions of service for teachers, and staff shortages across board

3. Government related challenges such as inadequate funding of tertiary institutions,

4. Student related challenges such as cultism, examination malpractice, social and academic vices (Egwu, 2009).

However, Udoka (2010), opined that the major challenge is funding. In the same vein, Yusuf and Soyemi (2012), posited that inadequate financing is one of the problems of implementing TVET curriculum in TVET institutions. Furthermore, Okoroafor (2010), also noted that; some of the problems of implementing TVET curriculum include;

1. Lack of sponsorship: Managers of educational institutions find it difficult to sponsor the TVET lecturers to seminars, conferences, and short courses claiming that there is lack of fund. This has affected the rate at which the TVET lecturers are upgraded.

2. Inadequate infrastructure: TVET lecturers do not have the opportunity to act what they have learnt into practice due to lack of infrastructure. 
3. Inadequate Timing: Time should be provided for TVET lecturers to go and upgrade themselves. Work load should not be so demanding that they preclude TVET lecturers form research and time to develop new skills, abilities and knowledge through research and innovation.

4. Lack of reward for excellence.

However, Nwogu and Nwanoruo (2011), Olaitan (1994) in Odu (2011), and Okebukola (2012), stated that the challenges of TVET are numerous, which include inadequate human and material resources in terms of quality and quantity; poor funding of TVET, inadequacies in infrastructural facilities; poor quality preparation of lesson by TVET teachers; and social vices. According to Mohammed (2005) in Ayonmike (2013), one of the problems of Technical and Vocational Education in Nigeria is the lack of motivated teachers and the reason for this lack of motivation could easily be traced to the low esteem of the teachers. More so, Onjewu (n.d.) posited that the lack of funds on the other hand affects other essentials needed in the implementation of technical education like the provision of teaching aids, furnishing of offices, laboratories, workshops and even basic infrastructures like classroom, seats and tables, so that a common sight to find students of architecture for instance sharing a table where each ideally should have one because of the technical nature of their course.

Ekpenyong (2011) in Ayonmike (2013) posited that, there are a number of factors, which have in various proportions impeded the smooth implementation of the goals and objectives of Technical and Vocational Education and Training (TVET). According to the National Board for Technical Education (NBTE, 2011), the underlining challenges of TVET sector include; low societal recognition, which translate to low enrolment and inadequate skilled workforce, obsolete instructional facility, inadequate funding, poor staffing, poor linkages with industry and general deficiency in quality. In addition, evaluation in all sectors of education tends to be by conventional examinations, which generally does not factor in practical techniques in the industry.

\subsection{Statement of Problem}

The implementation of TVET curriculum in technical colleges in Southern Nigeria needs attention. This became pertinent due to the fact that significant research on the challenges of implementing TVET curriculum in Nigeria have been conducted but in Southern Nigeria where about sixty government technical colleges are located, no study have sampled the opinion of technical college principals on the challenges of implementing TVET curriculum. Hence this study became necessary to examine whether Southern Nigeria technical 
college principals perceived the challenges of implementing TVET curriculum in Nigeria technical colleges as reported by TVET scholars.

\subsection{Purpose of the Study}

The purpose of this study is to examine the challenges of implementing TVET curriculum in government technical colleges in Nigeria. Specifically, the study is set out to examine the:

1. Challenges of implementing TVET curriculum in government technical colleges in South-South Nigeria

2. Challenges of implementing TVET curriculum in government technical colleges in South-West Nigeria

3. Challenges of implementing TVET curriculum in government technical colleges in South-East Nigeria

\subsection{Research Questions}

The following research questions were raised for the study:

1. What are the challenges of implementing TVET curriculum in government technical colleges in South-South Nigeria?

2. What are the challenges of implementing TVET curriculum in government technical colleges in South-West Nigeria?

3. What are the challenges of implementing TVET curriculum in government technical colleges in South-East Nigeria?

\subsection{Research Hypothesis}

It was hypothesized that is no significant difference in the response of principals from South-South, South-West, and South- East on the challenges of implementing TVET curriculum in government technical colleges Nigeria.

\section{$2 \quad$ Methods}

\subsection{Scope of the Study}

This study is on the challenges of implementing TVET curriculum in government technical colleges in Southern Nigeria. However, the study is limited in scope to examine the challenges of implementing TVET curriculum in government technical colleges in the three (3) geopolitical zones which are: South-South, South-West, and South-East Nigeria. 


\subsection{Population of the Study}

The population of the study is all the 110 principals from the 110 government technical colleges in Nigeria.

\subsection{Sampling and Sampling Technique}

The purposive sampling technique was used to select all sixty (60) principals of government technical colleges from Southern Nigeria. All the principals were used because of the limited numbers of principals. Table 1 below shows the distribution of sample from the three (3) geopolitical zones in Southern Nigeria.

Table 1: Distribution of Government Technical Colleges in Southern Nigeria

\begin{tabular}{ll} 
Geopolitical Zones & Numbers of Government Technical Colleges \\
\hline South-South & $21(35 \%)$ \\
South-West & $28(46.7 \%)$ \\
South-East & $11(18.3 \%)$ \\
Total Sample & $60(100 \%)$ \\
\hline
\end{tabular}

\subsection{Instrument and Data Quality}

Data were collected using a structured questionnaire titled "Challenges of Implementing Technical Vocational Education and Training Curriculum Questionnaire" (CITVETCQ) developed by the researcher. The CITVETCQ was divided into two parts. The first part sought information on selected data about government technical colleges. The second part consists of fifteen (15) items relevant to answering research questions posed in the study. The response format of CITVETCQ were based on an alternate response scale pattern of "Yes", "No", and "No Response".

The instrument was validated by two experts from the Department of Technical and Vocational Education, Nnamdi Azikiwe University, Awka, Anambra State and Delta State University, Abraka, Delta State of Nigeria. The experts agreed that the instrument was relevant and appropriate. As a result of their comments, some items were restricted to produce the final instrument. To determine the reliability of the instrument, ten (10) copies of the questionnaire were administered twice with an interval of four weeks to Heads of Department of Technical and Vocational Education of Federal and State Universities in Nigeria who were not part of the sample of this study. The test retest method was used to ascertain the reliability of the instrument using Pearson Product Moment Correlation Technique. The correlation coefficient obtained was 0.83 which was high and above the recommended acceptable value of 0.70 for good 
reliability (Wuensch, 2009). Therefore, the instrument was regarded as reliable enough for use in data collection for the study.

\subsection{Data Collection and Analysis}

The researcher, with the support of eighteen (18) field research assistants who are students of the Department of Technical and Business Education, Delta State University, Abraka, administered the questionnaire to the principals of all the government technical colleges in the three (3) geopolitical zones of Southern Nigeria. Six (6) field research assistants were assigned to each of the geopolitical zones in the study area to help with the data collection. Upon collection, the data were entered and analysed using frequency counts and percentages, so as to respond to the research questions raised. Chi-Square goodness of fit statistics was used to test the research hypothesis. This was done at the level of confidence alpha $=0.05$.

\section{Findings, Discussion and Conclusion}

The findings on the research questions and the hypothesis are summarized in Table 2. 
Ayonmike: Challenges in Implementing the TVET in Southern Nigeria

Table 2: Challenges in Implementing the TVET Curriculum

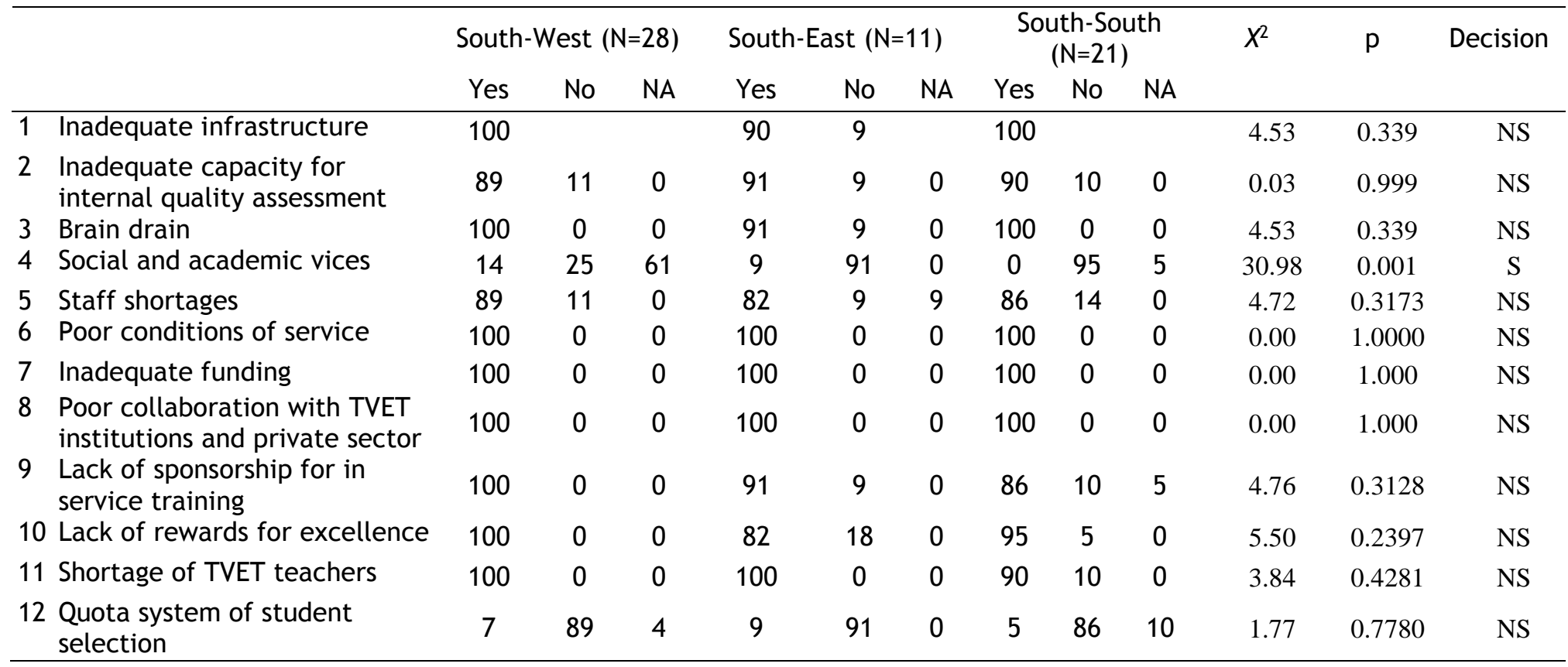


The result in Table 2 shows that the respondents from Southern Nigeria GTC agreed that, the challenges of implementing TVET curriculum include : inadequate and obsolete infrastructure and equipment, for example poor equipped TVET workshop and libraries, dilapidated classroom blocks, inadequate capacity in the institutions for internal/peer quality assessment, brain drain, staff shortages across board, poor conditions of service for teachers, inadequate funding of TVET institutions, inadequate collaboration between TVET institutions and organized private sector, lack of sponsorship for in service training for staff of TVET institutions, lack of reward for excellence for staff of TVET institutions, acute shortage of TVET teachers, insufficient material resources for training in TVET institutions, dearth of qualified TVET educators. Also, Table 2 shows the Chi-Square analysis for testing the hypothesis at 0.05 level of significance. The results in the table shows that the calculated Chi-Square value for the fourteen (14) item statement is less than the tabulated Chi-Square value at Degree of Freedom $(\mathrm{Df}=4)$ apart from item statement number four (4) whose Chi-Square value is greater than the tabulated Chi-Square value. However, the hypothesis stated in this study was accepted. This implies that there is no significant difference in the response of principals from South-South, South-West, and South- East on the challenges of implementing TVET curriculum in government technical colleges Nigeria.

Consequently, the results obtained in this study is similar to various research report of TVET scholars who posited that the challenges of TVET are numerous, which include inadequate human and material resources in terms of quality and quantity; poor funding of TVET, inadequacies in infrastructural facilities; poor quality preparation of lesson by TVET teachers; and social vices (Egwu (2009); Udoka (2010); Yusuf and Soyemi (2012); Okoroafor (2010); Mohammed (2005) in Ayonmike (2013); Okebukola (2012); Onjewu (n.d.); Ekpenyong (2011) in Ayonmike (2013); Nwogu and Nwanoruo (2011); Olaitan (1994) in Odu (2011); Odu (2011); UNESCO (2009); and (NBTE, 2011).Based on the findings of the study, it was concluded that the implementation of TVET curriculum in Southern Nigeria government technical colleges has been faced with various challenges which are synonymous with some of the problems of education in Nigeria such as poor funding, obsolete facilities and poor provision of instructional materials for effective implementation of TVET curriculum. Therefore, for effective implementation of TVET curriculum in Nigerian government technical colleges, the government, nongovernmental organization, international organizational, and stakeholders should work collectively to address the various challenges of implementing the curriculum and also to address the general educational problems of the nation. These could be achieved through proper funding, management, administration, and public private partnership to improve resources in implementing TVET curriculum in Nigerian GTC. 


\section{References}

Akerele, W.O. (2007). Management of technical and vocational education in Nigeria: the challenges of the country. Journal of Research in Education and Society. 1(2\&3): 117-124.

Akinseinde, .S.I. (2004). An appraisal of undergraduate curriculum of technical education in Nigerian universities: implications for higher education management. Makerere Journal of Higher Education 4(2).

Arowolo, A.A. (2010). Historical factors that influence curriculum development in industrial technical education. Retrieved $10^{\text {th }}$ September, 2012 from http://www.google.com.ng.

Ayonmike, C.S. (2013). Status of technical and vocational education in rural institutions in Delta State Nigeria. Makerere Journal of Higher Education, 5 (1): $81-90$.

Common Wealth of Learning (2000). Curriculum: theory, design and assessment. Retrieved $10^{\text {th }} \quad$ September, 2012 from http://www.gooogle.com.ng

Egwu, S. (2009). Universities and the national education roadmap. A Key-note Address by the Honourable Minister of Education on the Occasion of the 24 ${ }^{\text {th }}$ Conference of the Association of Vice-Chancellors of Nigerian Universities, at the University of Ilorin, on Tuesday June.

National Board for Business and Technical Education (n.d). State government technical colleges. Retrieved $31^{\text {st }}$ May, 2014 from www.nbte.gov.ng/inst_09.html

Nwogu, P.O. and Nweanomo, C.C (2011). Vocational technical education and training for self-reliance: towards national development. Mediterranean Journal of Social Sciences 5(5):55-59.

Odu, K.O. (2011). Human capital development in science and technology education: challenges and new responsibilities for the teacher. Contemporary Educational Technology 2(3):238-249

Okafoafor, C. (2010). Human capital development and vision 20:10. A perspective on tertiary education. SBMT Nekede Conference Journal. 1(2):71-73.

Udoka, S.I. (2010). The global economic crisis: a challenges to curriculum of implementation in technical and vocational education technology in Nigeria. Retrieved $20^{\text {th }} \quad$ August, 2013 from www.icidr.org/...2010/The\%20Global\%20Economic\%20Crisis\%20a\%20.

Ughamadu, K.A. (2006). Curriculum: concept of development and implementation. Onitsha, Lincel Publishers

Yusuf, M.A. and Soyemi, J. (2012). Achieving sustainable economic development in Nigeria through technical and vocational education and 
training: the missing link. International Journal of Academic Research in Business and Social Sciences. 2(2), 71-77. 